\title{
The Development of an Instrument on Negative Fractions to Measure the Cognitive Obstacle Based on Mental Mechanism Stages
}

\author{
Susiswo Susiswo ${ }^{1}$, Tatik Retno Murniasih ${ }^{2}$, Cholis Sa'dijah ${ }^{1}$, \\ Makbul Muksar ${ }^{1}$, Wasilatul Murtafiah ${ }^{3}$ \\ ${ }^{1}$ Universitas Negeri Malang, Jl. Semarang No. 5, Malang, Indonesia \\ ${ }^{2}$ Universitas PGRI Kanjuruhan Malang, Jl. S. Supriadi No.48, Malang, Indonesia \\ ${ }^{3}$ Universitas PGRI Madiun, Jl. Setiabudi No. 85, Madiun, Indonesia
}

\begin{abstract}
The cognitive obstacle is a thinking barrier of pre-service teachers caused by less meaningful learning and the difficult nature of fraction material. The pre-service teachers' cognitive obstacle measurement is done by giving negative fraction questions that contradict positive fractions. This research objective is to develop an instrument that can measure cognitive obstacles based on mental mechanism stages. This development research uses three stages of 4D development: defining, designing, and developing. The research participants were 71 preservice teachers from two different universities in Malang, Indonesia. The research findings show that questions of a negative fraction have a high level of validity in measuring the cognitive obstacle of preservice teachers. Triangulation is recommended for further research related to cognitive obstacles that arise when solving fraction problems of negative numbers.
\end{abstract}

Keywords - instrument, negative fraction, cognitive obstacle, mental mechanism

\section{Introduction}

The cognitive obstacle is a barrier to one's thinking when facing new contradictory problems [1]. The

DOI: $10.18421 /$ TEM103-44

https://doi.org/10.18421/TEM103-44

Corresponding author: Susiswo Susiswo,

Universitas Negeri Malang, Malang, Indonesia.

Email: susiswo.fmipa@um.ac.id

Received: 25 March 2021.

Revised: 31 July 2021.

Accepted: 05 August 2021.

Published: 27 August 2021.

(cc)BY-NC-ND (C) 2021 Susiswo Susiswo et al; published by UIKTEN. This work is licensed under the Creative Commons Attribution-NonCommercial-NoDerivs 4.0 License.

The article is published with Open Access at www.temjournal.com cognitive obstacle in learning material of fractions can be caused by less meaningful learning [2] and the difficult nature of fraction material [3],[4],[5].

People with cognitive obstacle have several characteristics such as generalizing the knowledge obtained to prior experience, relying on false intuition, and having a problem with language representation [6],[7],[8]. Poor understanding of positive fractions will hinder someone from learning negative fractions. Based on these characteristics, people thinking process will be hampered when facing a contradictory problem. For example, a problem in positive numbers will contradict with negative numbers [1].

Several researchers had examined the cognitive obstacle on positive number fractions. Research in Japan showed that untreated students had problems understanding the equal-whole of positive fractions [3]. Research in Canada showed that pre-service teachers were still experiencing cognitive obstacles when building a meaningful solution in solving positive fractions [4]. Meanwhile, several studies in Indonesia showed that cognitive obstacles occurred when solving positive fractions, such as misconceptions about fraction density and obstacle related to language representation [9],[10],[11].

It is necessary to develop an instrument to measure the cognitive obstacle of pre-service teachers on negative fractions learning material. Most of the preservice teachers still make many mistakes in solving negative fractions [12]. The instrument being developed refers to 3 characteristics of cognitive obstacles.

The negative fraction instrument is an instrument that contradicts a positive fraction. The different signs between positive and negative will lead to a contradictory concept [13],[14],[15]. The contradictory concept leads to cognitive obstacles [1],[16].

The cognitive obstacle can be measured based on the stages of the mental mechanism of APOS. The mental mechanism stages consist of interiorization, 
coordination, reversal, encapsulation, and deencapsulation [17]. The cognitive mechanism stages can be used to analyse pre-service teachers' understanding of fractions [17],[18],[19]. The experts' presentation explained why the pre-service teachers' cognitive obstacle on fraction problems could be analysed by the mental mechanism stages of the APOS theory.

The obstacle being experienced by pre-service mathematics teachers in Malang when facing negative fractions becomes the main problem of this research. The development of an instrument on negative fractions is needed to measure the cognitive obstacle. This research aims to develop a negative fraction instrument that can measure cognitive obstacles based on the mental mechanism stages. The instrument is developed based on cognitive obstacle indicators, including false intuitive obstacles, generalization obstacles, and language representation obstacles.

\section{Method}

The development framework refers to the 4D development stages by Thiagarajan [20]. This research type is development research. The instrument is developed to measure cognitive obstacle applies three stages of 4D development, namely defining, designing, and developing.

The defined stage includes several activities, including front-end analysis, pre-service teacher analysis, material analysis, and test analysis. The front-end analysis is a literature study on fractions given at the university to measure cognitive obstacles as instrument design and development according to the mental mechanism stages. The pre-service teachers' characteristics are used to analyse the development of instrument on negative fractions material. The material is analysed in detail to identify the material according to the curriculum in higher education. The test is designed to bring up the preservice teachers' cognitive obstacle related to negative fractions according to the mental mechanism stages. The design stage includes the development of an instrument that can measure the pre-service teachers' cognitive obstacle. The activities include analysing the learning objective and analysing the pre-service teachers at two private universities in Malang, generating a test grid. The cognitive obstacle indicators are adjusted to mental mechanism stages. The development stage is carried out in two steps, namely expert validation and development trials/testing. The development stage aims to produce the final instrument after going through expert revisions and trials.

The research subjects were 71 pre-service teachers from 2 private universities in Malang City, Indonesia. The pre-service teachers in question had already finished the course of Mathematical Foundation and School Mathematics Development
Studies 1. Both classes instill an understanding of numbers so that the candidates have sufficient cognitive knowledge to solve fraction problems [16]. The candidates were selected based on various abilities they already have. The research used several instruments, including tests, assessment scores, and validation. The test was arranged according to cognitive obstacles' characteristics, including language representation obstacle, generalization obstacle, and false intuitive obstacle. The test consisted of 2 fraction questions developed on negative numbers. The test instrument's development referred to the indicators of cognitive obstacles seen in Table 1.

Table 1. Indicators of the cognitive barrier according to mental mechanism stages

Barrier Indicator
- Understand the sentence "the fraction
will produce a value closest to one but
not equal to one" as an integer that is
closest to one but not equal to one
- Understand the sentence "the fraction
will produce a value closest to one but
not equal to one" as a fraction that has
the distance of zero from one
- Understand the sentence "the fraction
will produce a value closest to one but
not equal to one" as a fraction before
one
1.
2. - Understanding $\mathrm{C}$ - $\mathrm{D}=\mathrm{D}$ as everything
minus $\mathrm{D}$ will result in $\mathrm{D}$




\begin{tabular}{|c|c|c|}
\hline $\begin{array}{l}\frac{E}{0} \\
\frac{1}{0} \\
0 \\
2\end{array}$ & Barrier Indicator & 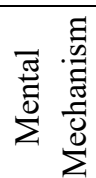 \\
\hline 2. & $\begin{array}{l}\text { - The process of determining all pairs of } \\
\text { subtractions that give } G \text {, namely: } A-G \\
=G, B-G=G, C-G=G, D-G=G \text {, } \\
E-G=G \text {, and } F-G=G \\
\text { - The process of determining } H-G=G \\
\text { and } G-E=G\end{array}$ & \\
\hline \multirow{3}{*}{1.} & $\begin{array}{l}\text { - The process of questioning back } \\
\frac{3}{1}-\frac{-7}{-4}=\frac{3-(-7)}{1-(-4)}=\frac{3+7}{1+4}=\frac{10}{5}=2 \\
\text { closest to } 1\end{array}$ & \multirow{4}{*}{ 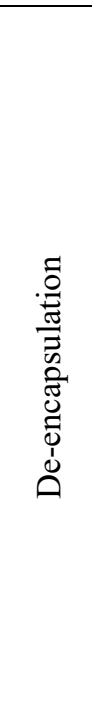 } \\
\hline & $\begin{array}{l}\text { - The process of questioning back } \\
\frac{1}{5}-\frac{3}{-4}=\frac{4+15}{20}=\frac{19}{20} \text { is closest to } 1\end{array}$ & \\
\hline & $\begin{array}{l}\text { - The process of questioning back that } \\
\frac{1}{3}--\frac{4}{6}=\frac{1}{3}+\frac{4}{6}=\frac{2+4}{6}=\frac{6}{6}= \\
1 \text {, one is the closest to one without } \\
\text { rereading the question }\end{array}$ & \\
\hline 2. & $\begin{array}{l}\text { - The process of questioning back that all } \\
\text { pairs of subtraction from } \mathrm{G} \text { will yield } \mathrm{G} \\
\text { - The process of questioning again that } \mathrm{H} \\
\text { and } \mathrm{G} \text { must be positive numbers }\end{array}$ & \\
\hline
\end{tabular}

The instrument test being developed is adapted from [21],[22]. The two developed test questions are presented in Table 2.

Table 2. Instrument being developed

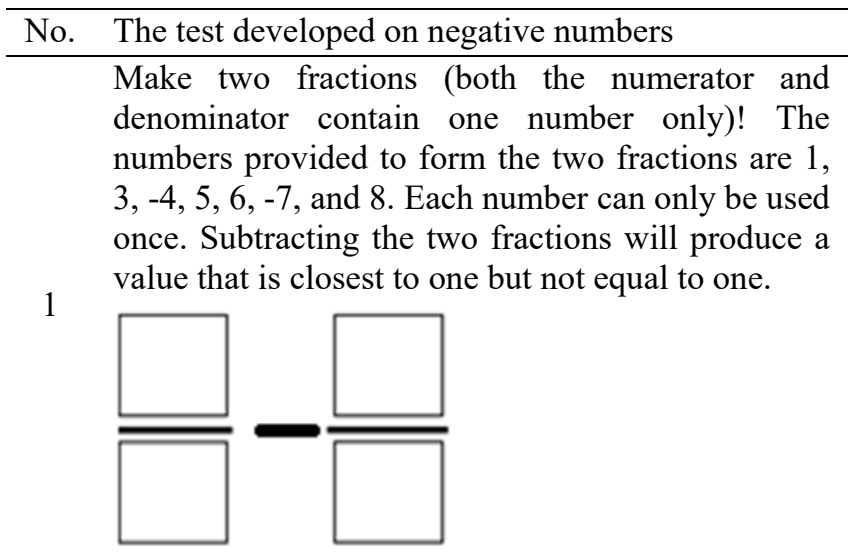

Given that $\mathrm{A}, \mathrm{B}, \mathrm{C}, \mathrm{D}, \mathrm{E}, \mathrm{F}, \mathrm{G}$, and $\mathrm{H}$ each represent a number on the number line. Each number can be subtracted, for example, $\mathrm{C}-\mathrm{D}=\mathrm{D}$ (by estimation). Using the estimation, write down

2 all pairs of subtraction that give the value $\mathrm{G}$ (in the Figure below)!
The second instrument being developed is the assessment score. The appropriate instrument assessment score can be seen in Table 3. below.

Table 3. Assessment scores according to mental mechanism stages

\begin{tabular}{clc}
\hline No. & \multicolumn{1}{c}{ Answer } & Score \\
\hline 1 & Correct up to the interiorization stage & 10 \\
\hline 2 & Correct until the coordination stage & 30 \\
\hline 3 & Correct until the reversal stage & 60 \\
\hline 4 & Correct up to the encapsulation stage & 90 \\
\hline 5 & $\begin{array}{l}\text { Correct up to the de-encapsulation } \\
\text { stage }\end{array}$ & 100 \\
\hline
\end{tabular}

This research uses two types of validity, namely content and construct. Validity is the compatibility level between the measuring instrument and the one to be measured [23]. Two validators carried out content validation from each of the two private universities in Malang. The validation sheet questions contain material ratings/assessment, barrier indicators, and language with a rating scale of 1 to 4 . The content validity was calculated using Aiken's V as follows [24],[25].

$\mathrm{V}=\sum(\mathrm{r}-1) /[\mathrm{n}(\mathrm{C}-1)]$

$\mathrm{r}=$ score given by the assessor

1 = lowest validity assessment score

$\mathrm{C}=$ highest validity assessment score

$\mathrm{n}$ = number of experts who made the assessment

This research involved four assessors and 4 rating scales. Aiken's V minimum standard for this research was 0.92 , with a probability of 0.020 [24]. Construct validity is used to identify the validity and reliability of the questions. The data were calculated using SPSS 21.

\section{Results and Analysis}

Validity describes the extent of compatibility between the measuring instrument and the one to be measured. Content validity is a series of questions related to material, barrier indicators, and language. In comparison, construct validity is the relationship between the test score and the theoretical construct prediction.

\subsection{Content Validity}

Before being tested on pre-service teachers, the instrument questions had been arranged based on indicators of cognitive obstacles on negative fractions material. Four validators carried out the validation. This assessment was carried out to determine content validity. The content validity coefficient was calculated based on Aiken's V. The calculated result was declared as valid when fulfilling the Aiken's V coefficient limit for 4 rating 
scales and four assessors, namely 0.92 with a probability of 0.020 . Aiken's V average score can be seen in Table 4. below.

Table 4. Aiken's V average score for the scoring rubric

\begin{tabular}{lc}
\hline \multicolumn{1}{c}{ Validation } & Average of Aiken's V \\
\hline Material & 0.96 \\
\hline Barrier indicator on the questions & 0.94 \\
\hline Language & 0.93 \\
\hline
\end{tabular}

Some suggestions for improvement from the validators, namely the need to pay attention to the command sentence in question number 1 that used an exclamation mark and pay attention to the spelling of the language in the questions. Meanwhile, the other validators gave revisions related to the language in question 2.

\subsection{Construct Validity}

The validity and reliability of the questions using SPSS can be seen in Table 5. and Table 6. below.

Table 5. Result of question validation

\begin{tabular}{cccc}
\hline Problem & Problem 1 & Problem 2 & Criteria \\
\hline $\mathrm{t}$ count & 4.71 & 3.76 & valid \\
\hline $\mathrm{t}$ table & 1.99 & 1.99 & valid \\
\hline
\end{tabular}

The questions are declared as valid if $t$ count $\geq t$ table. Based on Table 5., it is obtained that $t$ count for question 1 is greater than $\mathrm{t}$ table for question 1 , namely $4.71>1.99$, and $t$ count for question 2 is greater than $t$ table for question 2, namely $3.76>$ 1.99. It means that question 1 and question 2 can be declared as valid.

The result of the questions' reliability can be seen in Table 6. below.

\section{Table 6. Reliability statistics}

\begin{tabular}{ccc}
\hline $\begin{array}{c}\text { Cronbach's } \\
\text { alpha }\end{array}$ & $\begin{array}{c}\text { Cronbach's alpha based } \\
\text { on standardized items }\end{array}$ & $\begin{array}{c}\mathrm{N} \text { of } \\
\text { Items }\end{array}$ \\
\hline .215 & .262 & 3 \\
\hline
\end{tabular}

Based on Table 6., it can be seen that $0.262>0.05$ so that the questions can be declared as reliable.

The result of the content validity shows a valid value because it fulfils Aiken's V coefficient. This means that the questions are appropriate and relevant to the objectives to be achieved. This research aims to develop and validate a negative fraction instrument to measure the cognitive obstacle of pre- service mathematics teachers according to mental mechanism stages. The research's initial stage was carried out by analysing the pre-service teachers, the material, and the literature studies related to fraction material in college. According to the expert, the content is in the category of valid.

In this research, an instrument to measure cognitive obstacles to negative fractions learning material has been developed. At the same time, previous studies revealed only a cognitive obstacle to positive fractions learning material [9],[26],[16]. Other researches showed the cognitive obstacle to negative integers [1],[27].

In measuring the cognitive obstacle on negative fractions, mental mechanism stages from APOS were used. This is in line with another research that stated that APOS's mental mechanism stages could be used to analyse the understanding of pre-service teachers regarding fraction material [17]. APOS theory can also be used to analyse teaching on numbers of material in universities [19]. Also, the APOS theory can explore pre-service teachers' understanding of fraction material [18]. The experts' presentation explained why the process of pre-service teachers' obstacle on the problem of fractions could be analysed using the APOS theory.

This research results show a valid and reliable development instrument. However, the research has limitations as follows: (a) the small number of sample size, and (b) not using the triangulation process at the time the cognitive obstacle was arising in solving problems on negative numbers. Modification and revision are required for the instrument being developed.

Based on the statistical result, negative fraction questions that can measure the cognitive obstacle of pre-service mathematics teachers were found. Future researches are suggested to use triangulation related to the cognitive obstacle that arises when solving negative fraction questions.

\section{Conclusion}

The research findings show that negative fraction questions have a high level of validity. The questions can be used to measure the cognitive obstacle of preservice teachers when solving fraction problems. Two questions instrument had been developed to measure the cognitive obstacle of pre-service mathematics teachers. The developed instrument can be applied in a learning process to measure the cognitive obstacle of pre-service mathematics teachers on fraction problems because it has high validity and reliability. 


\section{References}

[1]. Bishop, J. P., Lamb, L. L., Philipp, R. A., Whitacre, I., Schappelle, B. P., \& Lewis, M. L. (2014). Obstacles and affordances for integer reasoning: An analysis of children's thinking and the history of mathematics. Journal for Research in Mathematics Education, 45(1), 19-61.

https://doi.org/10.5951/jresematheduc.45.1.0019

[2]. Prediger, S. (2008). The relevance of didactic categories for analysing obstacles in conceptual change: Revisiting the case of multiplication of fractions. Learning and instruction, 18(1), 3-17. https://doi.org/https://doi.org/10.1016/j.learninstruc.2 006.08 .001

[3]. Yoshida, H., \& Sawano, K. (2002). Overcoming cognitive obstacles in learning fractions: Equalpartitioning and equal-whole 1. Japanese Psychological Research, 44(4), 183-195.

https://doi.org/10.1111/1468-5884.00021

[4]. Osana, H. P., \& Royea, D. A. (2011). Obstacles and challenges in preservice teachers' explorations with fractions: A view from a small-scale intervention study. The Journal of Mathematical Behavior, 30(4), 333-352.

https://doi.org/https://doi.org/10.1016/j.jmathb.2011.0 7.001

[5]. Deringöl, Y. (2019). Misconceptions of Primary School Students about the Subject of Fractions. International Journal of Evaluation and Research in Education, 8(1), 29-38. https://doi.org/10.11591/ijere.v8i1.16290

[6]. Sbaragli, S., Arrigo, G., D'Amore, B., Fandiño Pinilla, M. I., Frapolli, A., Frigerio, D., \& Villa, O. (2011). Epistemological and Didactic Obstacles: the influence of teachers' beliefs on the conceptual education of students. Mediterranean journal for research in mathematics education, 10, 61-102.

[7]. Booth, J. L., Newton, K. J., \& Twiss-Garrity, L. K. (2014). The impact of fraction magnitude knowledge on algebra performance and learning. Journal of experimental child psychology, 118, 110-118.

[8]. Prediger, S., \& Wessel, L. (2010). Relating registers for fraction-Multilingual students on their way to conceptual understanding. ICMI Study, 324-333.

[9]. Purnomo, Y. W., Kowiyah, Alyani, F., \& Assiti, S. S. (2014). Assessing number sense performance of Indonesian elementary school students. International Education Studies, 7(8), 74-84. https://doi.org/http://dx.doi.org/10.5539/ies.v7n8p74

[10]. Murniasih, T. R., Sa'dijah, C., Muksar, M., \& Susiswo, S. (2018). Errors in representation translation in solving problems related to number sense of pre-service math teachers. In Proceedings of the Annual Conference on Social Sciences and Humanities (ANCOSH) (pp. 393-399).

[11]. Apriandi, D., Murtafiah, W., Ayuningtyas, A. D., \& Rudyanto, H. E. (2020, August). Solving Shortest Path Problems Using Mathematical Literacy Skill Figured Out By Pre-Service Teachers. In Journal of Physics: Conference Series (Vol. 1613, No. 1, p. 012016). IOP Publishing.

https://doi.org/10.1088/1742-6596/1613/1/012016
[12]. Widjaja, W., Stacey, K., \& Steinle, V. (2011). Locating negative decimals on the number line: Insights into the thinking of pre-service primary teachers. The Journal of Mathematical Behavior, 30(1), 80-91. https://doi.org/10.1016/j.jmathb.2010.11.004

[13]. Fuadiah, N. F., \& Suryadi, D. (2017). Some Difficulties in Understanding Negative Numbers Faced by Students: A Qualitative Study Applied at Secondary Schools in Indonesia. International Education Studies, 10(1), 24-38.

[14]. Vlassis, J. (2008). The role of mathematical symbols in the development of number conceptualization: The case of the minus sign. Philosophical Psychology, 21(4), 555-570. https://doi.org/10.1080/09515080802285552

[15]. Bofferding, L., Hoffman, A., Suazo, E., \& Lisy, N. (2015). Number Line Estimation With Negatives. In Proceedings of the 37th annual meeting of the North American Chapter of the International Group for the Psychology of Mathematics Education. (pp. 133140).

https://doi.org/https://files.eric.ed.gov/fulltext/ED584 204.pdf

[16]. Murniasih, T. R., Sa'dijah, C., Muksar, M., \& Susiswo, S. (2020). Fraction Sense: An Analysis of Preservice Mathematics Teachers Cognitive Obstacles. Center for Educational Policy Studies Journal, 10(2), 27-47. https://doi.org/10.26529/cepsj.742

[17]. Dubinsky, E., Arnon, I., \& Weller, K. (2013). Preservice Teachers' Understanding of the Relation Between a Fraction or Integer and its Decimal Expansion: The Case of $0.9^{-}$and 1. Canadian Journal of science, mathematics and Technology education, 13(3), 232-258. https://doi.org/10.1080/14926156.2013.816389

[18]. Ubah, I. J., \& Bansilal, S. (2018). Pre-service primary Mathematics teachers' understanding of fractions: An action-process-object-schema perspective. South African Journal of Childhood Education, 8(2), 1-12.

https://doi.org/10.4102/sajce.v8i2.539

[19]. Voskoglou, M. G. (2013). An application of the APOS/ACE approach in teaching the irrational numbers. Journal of Mathematical Sciences and Mathematics Education, 8(1), 30-47.

https://doi.org/https://doi.org/10.29333/ejmste/91451

[20]. Thiagarajan, S, Semmel, D, Semmel, M Instructional development for training teachers of exceptional children: A sourcebook1974MinneapolisUniversity of Minnesota, Leadership Training Institute/Special Education https://doi.org/10.1016/00224405(76)90066-2

[21]. Clarke, D. M., Roche, A., \& Mitchell, A. (2011). One-to-one student interviews provide powerful insights and clear focus for the teaching of fractions in the middle years. In Fractions. Taching for Understanding (pp. 23-32). The Australian Association of Mathematics Teachers (AAMT) Inc..

[22]. Mcintosh, F., \& Sense, B. N. (1997). Number Sense Item Bank, 1-15. 

[23]. Brown, H. D., \& Abeywickrama, P.
(2010). Language assessment: Principles and classroom practices (Vol. 10). White Plains, NY: Pearson Education.

[24]. Aiken, L. R. (1985). Three coefficients for analyzing the reliability and validity of ratings. Educational and psychological measurement, 45(1), 131-142. https://doi.org/10.1177/07399863870092005

[25]. Bashooir, K., \& Supahar, S. (2018). Validitas dan reliabilitas instrumen asesmen kinerja literasi sains pelajaran fisika berbasis STEM. Jurnal penelitian dan evaluasi pendidikan, 22(2), 219-230. https://doi.org/10.21831/pep.v22i2.20270
[26]. Olanoff, D., Feldman, Z., Welder, R. M., Tobias, J. M., Thanheiser, E., \& Hillen, A. F. (2016). Greater Number of Larger Pieces: A Strategy to Promote Prospective Teachers' Fraction Number Sense Development. North American Chapter of the International Group for the Psychology of Mathematics Education.

[27]. Zakaria, E., Ibrahim, \& Maat, S. M. (2010). Analysis of Students' Error in Learning of Quadratic Equations Effandi. International Education Studies, 3(3), 105110.

https://doi.org/10.1111/j.0886-0440.2005.200343.x 